\title{
Applying quality concepts to achieve environmental sustainability in the freight transport sector - reviewing process management and lean
}

Priscilla Navarro

The self-archived postprint version of this journal article is available at Linköping University Institutional Repository (DiVA):

http://urn.kb.se/resolve?urn=urn:nbn:se:liu:diva-176833.

N.B.: When citing this work, cite the original publication.

Navarro, P., (2021), Applying quality concepts to achieve environmental sustainability in the freight transport sector - reviewing process management and lean, International Journal of Quality and Service Sciences. https://doi.org/10.1108/IJQSS-02-2020-0029

Original publication available at:

https://doi.org/10.1108/IJQSS-02-2020-0029

Copyright: Emerald

http://www.emeraldinsight.com/ 


\title{
Applying quality concepts to achieve environmental sustainability in the freight transport sector - Reviewing process management and lean
}

\begin{abstract}
Purpose - The purpose of this paper is to revisit lean manufacturing and process management to review how they have targeted environmental sustainability and determine whether they have the potential to achieve environmental sustainability in small and medium-sized companies within the freight transport sector.

Design/methodology/approach - The methodology for this paper was divided into three steps. First, a narrative literature review, including previously designed search strings. The second step involved a snowball approach, where the identification of new sources departed from previously selected articles. The third step included a completing narrative review to search for the most recent articles published related to the purpose. The analysis was based on the identification of benefits, challenges and the potential of lean and process management to deal with environmental demands among transport companies.
\end{abstract}

Findings - The findings suggest a potential of lean and process management for achieving environmental sustainability, if adapted appropriately.

Research limitation/implication - This study included two of the concepts from the quality movement from a literature perspective. Hence, there is a need for research to evaluate these results empirically. Additionally, other aspects should be studied within the quality movement for achieving environmental sustainability.

Originality/value - This paper aims to be a basis and a path for further theoretical and empirical research for the quality movement to support environmental sustainability. This paper particularly aims to fill part of the gap in the literature on how the freight transport sector can enhance environmental sustainability in its operations.

Keywords Process management, Lean manufacturing, Environmental sustainability, Road freight transport.

\section{Introduction}

Over the years, Quality Management (QM) has focused on the identifying and fulfilling customer requirements to achieve customer satisfaction. However, research points towards a broadening in the focus of QM, by adding societal satisfaction as one of its objectives (Deleryd and Fundin, 2015). Originally, QM was designed and developed to achieve a more effective use of resources and higher customer satisfaction. Hence, QM has been used by organisations to gain a competitive advantage. The broadening of the focus of QM has led many researchers to direct efforts towards investigating how QM could support the achievement of new needs.

Garvare and Johansson (2010) are some of the researchers that have identified the need for QM to be re-studied. They present a conceptual model that shows that the requirements for organisations are determined by several parties; primary and secondary stakeholders are the main parties to consider. The authors mention that organisations need to focus on their primary stakeholders, usually represented by the customers, co-workers, suppliers, shareholders, and other actors that may have direct control over the outcomes of the organisation. However, and more interestingly, they specify the importance of attending to the needs of the secondary stakeholders. These kinds of stakeholders are defined by the authors as parties that could influence primary stakeholders when their needs are not fulfilled, or their interests are not considered. Societal satisfaction might be included in the needs of both kinds of stakeholders. Nevertheless, there might be additional pressure from secondary stakeholders towards primary stakeholders in terms of some 
specific needs. For example, environmental organisations could pressure customers to demand a lower environmental impact in the products or services that an organisation offers.

Based on this conceptual model and the considerations made by Deleryd and Fundin (2015), it is important to be able to identify all these stakeholders' existing and latent needs. Moreover, it is essential to establish ways for the organisations to manage their resources to achieve both customer and societal satisfaction. As mentioned by Garvare and Johansson (2010), this might be a constraint on the customer focus traditionally targeted by QM. This constraint presupposes a gap in literature and in practice about the way QM can contribute to achieving societal satisfaction. There is a need to revisit the concepts included in QM to investigate whether they are able to satisfy requirements to achieve societal satisfaction in the same way they have supported the achievement of customer satisfaction in the past.

The current study is a contribution towards filling that gap. For this contribution, a specific societal need was selected, sustainability. Sustainability deals with not over-utilising resources and preserving them for future generations and is divided into three elements: Social, Economic and Environmental (Brundtland, 1987). This paper focuses on environmental sustainability, a societal and critical demand that has increased in popularity over recent decades. Environmental groups and many parts of society pressure customers and governments into demanding environmentally sustainable solutions from organisations. Moreover, the personal interest of customers in products and services with lower environmental impact has increased in recent decades. Nonetheless, it is not usually a concrete demand or a priority that the customers directly state to organisations. Hence, this study deals with the enhancement of environmental sustainability in organisations using two concepts from QM, process management and lean manufacturing.

As a way to narrow down the objective of the study, the specific context of the road freight transport business sector was selected. Fast-changing requirements, low margin and extreme competitive pressures are some of the characteristics associated with the road freight transport business sector (e.g. Oskarsson et al, 2003; Evangelista and Sweeney, 2014). Within logistics, freight transportation is a sector that contributes largely to the environmental impact (Márquez-Ramos, 2015). Previous research within the freight transport sector highlights efforts made to reduce the environmental impact but, in practice, a lack of tools to increase the sustainability of freight transport has been evidenced (Aronsson and Brodin, 2006; Isaksson, 2012; Evangelista et al, 2013; Martinsen and Huge-Brodin, 2014). Hence, this business sector constitutes a context where environmental sustainability is evidently a current need for both primary and secondary stakeholders.

Within the quality movement, process management and lean manufacturing have proved in the past to be effective in achieving better solutions and results in companies, regarding resources such as economics, time and materials (e.g. Liker and Meier, 2006; Bergman and Klefsjö, 2010; Palmberg, 2010). However, due to the current global need to deal with a new demand, namely environmental sustainability, it is necessary to discover new approaches to manage environmental requirements. These new approaches might include revisiting the current concepts to determine whether they could help in the quest towards becoming more environmentally sustainable. Among the concepts considered to require a revision are principles, methodologies, tools and philosophies included in QM. As mentioned by Kuei and H. Lu (2013), transitioning from a traditional approach towards one where sustainability is embedded is not an easy task. These authors developed a conceptual model for integrating QM principles with Sustainability Management. They refer to SM as a means to achieve economic development, environmental performance and social equity simultaneously. In their paper they also identify the gap among QM concepts to target the different aspects of the triple bottom line of sustainability.

Hence, the purpose of this paper is to revisit two of those QM concepts, namely lean manufacturing and process management, to review how they have targeted environmental sustainability, and to determine whether they have the potential to achieve environmental sustainability in companies in the freight transport sector. 
To achieve this purpose, the following research questions were designed.

RQ1: How has process management previously been used to achieve environmental sustainability?

RQ2: How has lean manufacturing previously been used to achieve environmental sustainability?

RQ3: What is the potential for process management to enhance the greening of the freight transport sector?

RQ4: What is the potential for lean manufacturing to enbance the greening of the freight transport sector?

This first section of the paper presents the background, purpose and research questions for the paper. The second section constitutes a theoretical background, which provides the theoretical base for the development of the paper. The third section includes the method, followed by the findings. Finally, the analysis is presented, followed by the conclusions of the paper.

\section{Theoretical Background}

For the development of this paper, two main areas are being targeted: process management, and lean manufacturing. These two areas are considered to be important concepts in QM. Process management is a methodology from QM (Paim et al, 2008; Palmberg, 2009) while lean manufacturing is considered a philosophy with its basis in QM values (e.g. Womack and Jones, 2003). Therefore, they are presented in this section.

\section{Process management}

To explain process management, a definition of a process is needed. Within research, there is a lack of a universal and generalizable definition for process (Palmberg, 2009). However, several of the existing definitions reflect the view for process used for this paper (i.e., Harrington, 1991; Hammer and Champy, 1993; Davenport, 1993; Bergman and Klefsjö, 2010). Based on these definitions, for the purpose of this paper, process will be considered to be a sequence of activities that give value to an input, from a customer perspective; and deliver an output to a customer, which may be internal or external.

Process management is also a concept that lacks a generalizable definition, even when several authors within the academic environment mention and study this methodology (Cronemyr, 2007; Paim et al, 2008; Bergman and Klefsjö, 2010; Cronemyr and Danielsson, 2013). Based on the existing definitions, for this paper, process management is considered to be a methodology for handling the operation and continual improvement of processes for creating value for customers, while reducing waste.

This methodology makes use of several tools that are present within TQM, such as process mapping, measurement, control, re-engineering and re-design (Psomas et al, 2011). According to Cronemyr (2007) and Cronemyr and Danielsson (2013), process management should be implemented in certain steps (see Figure 1) to ensure successful implementation. Process management handles the way organisations work from the design and establishment of processes to the management and continuous improvement of those processes. It involves measurements, establishing goals and the development of teams dedicated to leading the organisation into a path they can follow to achieve their strategic goals and gain a competitive advantage in the markets to which they belong.

The process management methodology has been proven to be successful in several business sectors in achieving higher quality and customer satisfaction (i.e. Shewhart 1931, 1939; Balzarova et al, 2004; Palmberg, 2009; Cronemyr and Danielsson, 2013). This methodology has helped many organisations to successfully identify the needs of their customers and determine ways to work to achieve customer satisfaction. That is, considering the traditional view of customers. Therefore, there is a need to determine whether the methodology is successful for satisfying the needs of other stakeholders, both primary and secondary.

This methodology has not yet been found to be successfully applied within the freight transport sector (Navarro, 2019). ISO 9000 is a standard used for guiding the implementation and operation of quality management systems (Poksinska, 2010). This standard has a process approach for 
management and operations. For decades, process management and the benefits of its implementation have been researched in many industrial contexts. However, logistics and freight transports are two sectors in which process management has only been applied sparsely (Navarro, 2019).

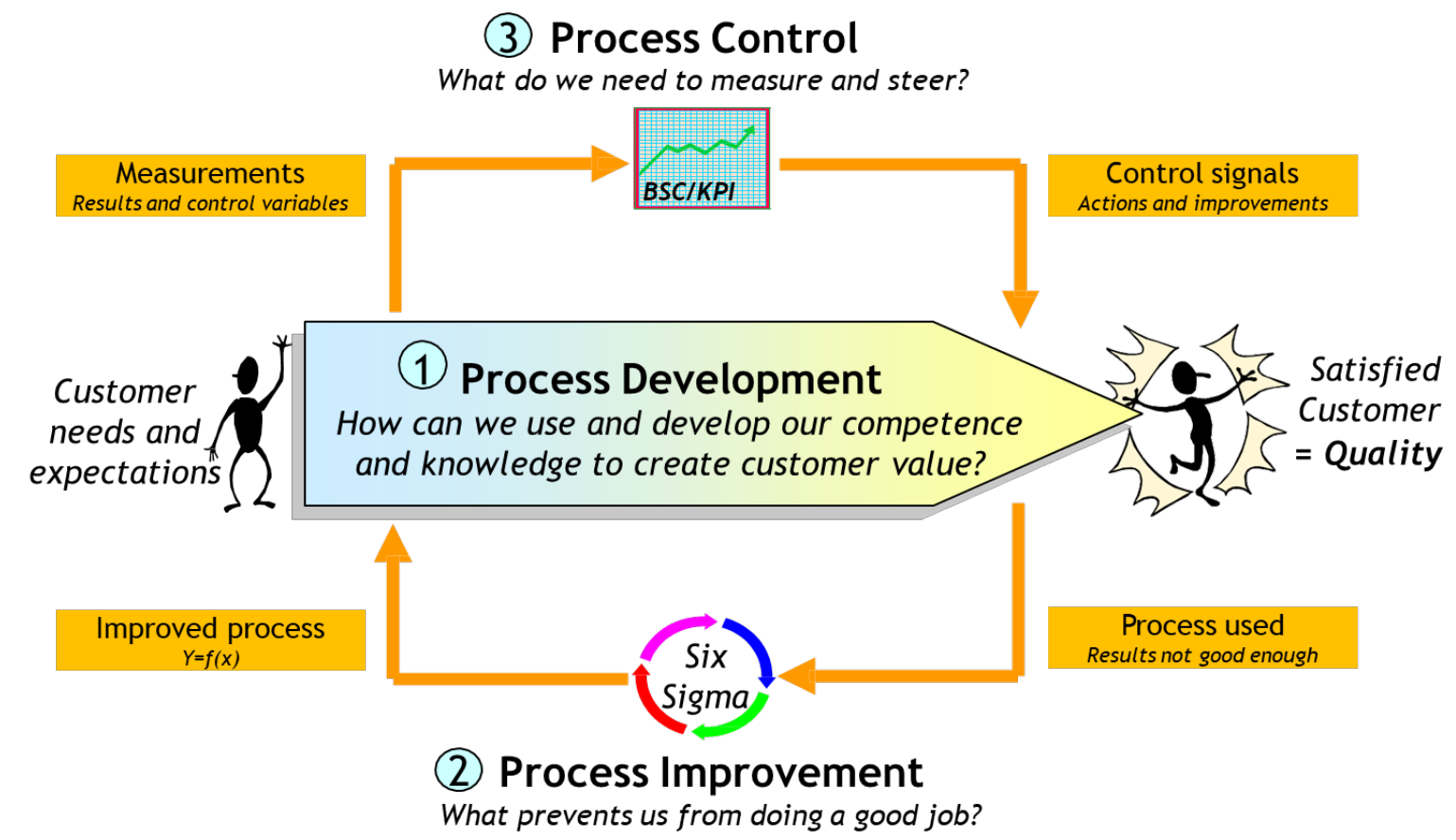

Figure 1. Process management 1-2-3. Taken from Cronemyr (2007, p.62)

\section{Lean manufacturing}

According to Sörqvist (2013), lean is a common way to refer to lean manufacturing and is a way to look at, manage and lead an organisation in ways that are resource efficient, flexible and fast. He explains that the objective with lean is to focus on customers and their needs, as well as on quality and not on short term financial results. Other authors (Womack et al, 1990; Womack and Jones, 2003; Liker and Meier, 2006) add that lean processes not only deliver high quality to the customer but also target the elimination of waste in terms of costs, time and materials. They also mention that lean is a set of tools for identifying and eliminating waste. According to the two authors, there are eight types of waste targeted in lean. Overproduction is the first one and refers to producing earlier on in greater quantities than needed. Waiting is the second kind of waste; it refers to the time during which a person or machine is idle while waiting for another step to start. The third waste refers to unnecessary transportations for a production. Unneeded operations in a product are also a kind of waste, called over processing. The fifth waste is excess of inventory, which involves having more raw material, work in process or finished goods than needed.

Unnecessary movements constitute the sixth type of waste and refer to all the movements that a person must do to produce an item or service that does not add value to it. One of the most obvious wastes is the seventh type, defects; it refers to all the parts that are defective or that need correction to become acceptable. The eighth and maybe least obvious of them all is unused employee creativity. Liker and Meier (2006) explain that the loss of ideas, time, skills and possibilities for improvement from not listening to employees is also considered a form of waste. Overall, these types of waste evidence that lean involves the elimination of steps, activities, material and mistakes that do not add value to the customer (Womack and Jones, 2003). All these types of waste are targeted by different tools within the lean philosophy, such as Just-in-time, Kaizen, PokaYoke and 5S (Womack et al, 1990; Sörqvist, 2013).

This philosophy was designed for a production environment, where the products offered to the customer were tangible. However, it is no secret that lean is also used in services. Over the years, this philosophy has gained territory in the research of management for different industries, such as 
healthcare (i.e. de Souza, 2009); information technology (i.e. Ghobakhloo and Hong, 2014) and education (Antony et al, 2012). Logistics has not been the exception to this trend and several researchers have focused on studying the implementation of lean in the field of logistics (i.e. Bednár et al, 2012; Prajogo et al, 2016; Ugarte et al, 2016).

\section{Method}

To develop this paper, the first stage was to develop a semi systematic literature review and a narrative literature review. The literature reviews aimed at finding sources that could provide relevant information to answer the research questions and target the purpose presented in the first section of the paper.

In a second stage, a thematic analysis was done by determining the relevancy of the sources and finding answers to the research questions. These two stages are explained below.

\section{The literature reviews}

The literature review was done by the means of a semi-systematic literature review (Snyder, 2019) and a narrative literature review, with a snowball approach (Smith, 2012). These kinds of literature reviews were selected due to the intention to map the state of knowledge in the area and to develop a basis for an agenda for further research (Snyder, 2019).

The first step for the literature review consisted of a semi-systematic literature review based on the search strings shown in Table 1. In the table, each search string is presented together with the research question(s) it was intended for. The search was performed in the database Scopus due to the quantity of peer reviewed articles it includes.

Table 1. Search strings for semi-systematic literature review

\begin{tabular}{|c|l|}
\hline \multicolumn{1}{|c|}{ Search String } & \multicolumn{1}{|c|}{ Research question } \\
\hline "Process management" AND environm* & RQ1, RQ3 \\
\hline "Process management" AND environmental sustainab* & RQ1, RQ3 \\
\hline $\begin{array}{c}\text { "Process management" AND environm* AND freight OR } \\
\text { transport* }\end{array}$ & RQ3 \\
\hline Lean OR Lean manufacturing AND environm* & RQ2, RQ4 \\
\hline $\begin{array}{c}\text { Lean OR Lean manufacturing AND environmental } \\
\text { sustainab* }\end{array}$ & RQ2, RQ4 \\
\hline $\begin{array}{l}\text { Lean OR Lean manufacturing AND environm* AND freight } \\
\text { OR transport* }\end{array}$ & RQ4 \\
\hline *is a wildcard & \\
\hline
\end{tabular}

The results for each of the search strings were then filtered according to 3 filters (see Table 2). The first filter (Filter A) involved articles written in English referring to the areas of engineering, management and/or logistics. The second filter (Filter B) was performed according to the title of the articles, discarding sources that did not relate to the purpose or the research questions of this study. Finally, the third filter (Filter C) was the content of the abstracts. This filtering process resulted in 45 articles, of which 9 were repeated and one was not available to be read. All the 35 articles were then read from this step of the literature review. These 35 articles were read and filtered according to their relevance to the research questions and purpose of the paper.

The second step of the literature review was done based on the results of the first step. From the resulting articles, new sources were identified, which was an iterative process and therefore is referred to as snowball approach (Smith, 2012). A total of 17 articles and two book chapters were considered after this step. They were also read and filtered according to their relevance to the research questions and purpose of the paper.

A previous version of this paper was presented at a quality management conference in 2018. Since environmental sustainability is a prospering global topic, a third and final literature review was 
performed. This review was a completing search, with a snowball approach from the results of the previous steps of the literature review, filtering by articles published as of 2018 to find more recent sources for the study. A total of five articles were read from this final step of the literature review. The results of each of the steps required to perform the literature review for this study are summarized in Table 2 .

Table 2. Results from the literature reviews

\begin{tabular}{|c|c|c|c|c|}
\hline Search string & $\begin{array}{l}\text { Initial } \\
\text { results }\end{array}$ & $\begin{array}{c}\text { Filter } \\
\text { A }\end{array}$ & $\begin{array}{c}\text { Filter } \\
\text { B }\end{array}$ & $\begin{array}{c}\text { Filter } \\
\mathrm{C}\end{array}$ \\
\hline "Process management" AND environm* & 2043 & 367 & 61 & 3 \\
\hline "Process management" AND environmental sustainab* & 11 & 11 & 6 & 4 \\
\hline $\begin{array}{l}\text { "Process management" AND environm* AND freight OR } \\
\text { transport* }\end{array}$ & 25 & 25 & 4 & 3 \\
\hline Lean OR Lean manufacturing AND environm* ${ }^{*}$ & 6878 & 1274 & 79 & 22 \\
\hline Lean OR Lean manufacturing AND environmental sustainab* & 56 & 19 & 14 & 8 \\
\hline $\begin{array}{l}\text { Lean OR Lean manufacturing AND environm* AND freight OR } \\
\text { transport* }\end{array}$ & 174 & 23 & 6 & 5 \\
\hline \multicolumn{5}{|l|}{ *is a wild-card } \\
\hline Articles from semi-systematic literature review & \multicolumn{4}{|c|}{45} \\
\hline Repeated articles from semi-systematic literature review & \multicolumn{4}{|c|}{9} \\
\hline Articles not available & \multicolumn{4}{|c|}{1} \\
\hline Articles read from semi-systematic literature review & \multicolumn{4}{|c|}{35} \\
\hline Snowballing & \multicolumn{4}{|c|}{17 articles, 2 book chapters } \\
\hline Snowballing (2018)** & \multicolumn{4}{|c|}{5 articles } \\
\hline **Completing literature review & & & & \\
\hline
\end{tabular}

The analysis

For the analysis, the articles from all the steps were read and scanned for aspects and subjects within the articles that related to the research questions and purpose of the paper. This constituted a familiarisation with the data and the subject. The data were then catalogued into different themes such as the principles, benefits and challenges found within process management and lean and how they are used to achieve environmental sustainability. Finally, the analysis section of this paper was developed by contrasting, comparing, and reflecting on the findings.

\section{Findings}

The following section presents the findings from the literature reviews. To present the findings more clearly, this section has been divided into two parts. The first part presents the findings for the use of process management in environmental sustainability while the second part refers to the use of lean to achieve environmental sustainability.

\section{Process management and environmental sustainability}

Process management has been used in many industries, such as manufacturing, public service and banking. In many cases it has proved to be the means to achieve lower costs, better customer satisfaction and higher quality (Paim et al, 2008). However, research on how it supports environmental sustainability is still in its early stages. Some researchers mention the beginning of Green Business Process management as a new research discipline which combines business process management and environmental impact (e.g. Houy et al ,2010; Opitz et al, 2014). Houy et al (2014) mention that common tools can support the improvement of resource efficiency and the simplification of service processes to achieve sustainability. However, they mention that the tools need to be adapted and to evolve from a support of business processes focused on costs and time 
to support the sustainability and resource efficiency of those processes. Additionally, they propose that the waste of the different steps in a process can be measured and, in turn, the entire consumption of resources for the process can be estimated. Similarly, Ghose et al (2009) highlight the potential of business processes to be the basis for measuring the carbon footprint $\left(\mathrm{CO}_{2}\right)$. $\mathrm{By}$ modelling and controlling the emissions at every step of the process, they state that it is possible to measure the emissions for the entire process.

Houy et al (2010) mention as one of the challenges of applying process management to achieve environmental sustainability is one of its main targets. One of process management's main targets is the reduction of unnecessary costs and even if environmental sustainability is important for many organisations, the economical factor is still the deal maker. Another of the challenges they mention is the lack of experience in using process management to enhance environmental sustainability.

Maletič et al (2014) distinguish two types of sustainable development, sustainability exploitation and sustainability exploration. These authors explain that while the former includes elements related to the use of resources, such as efficiency, measurement and the exploitation of sustainability competences, the latter relates to "challenging existing sustainability solutions with innovative concepts and developing capabilities and competencies for sustainability-related innovation". They suggest that process management supports sustainability exploitation by the use of performance measurement and continuous process improvements on existing processes to enhance competitive advantage. On the other hand, process management supports sustainability exploration by searching for opportunities to develop and improve new processes, use alternative and innovative technologies and support the dynamic change of the organisations. In a later article, Maletič et al (2015) explain that with process management exploitation, particularly with performance indicators and variability reduction, it is possible for companies to obtain better results for environmental and also economic aspects of sustainability.

Recker et al (2010) mention that one of the main goals for organisations that strive towards environmental sustainability is to decrease the carbon footprint of their operations. They present several approaches that have been adopted to decrease the carbon footprint from a process perspective. Among the approaches, the authors mention the hybrid-EIO-LCA, where a process analysis approach and an environmental input-output analysis are merged. This hybrid approach involves measuring the inputs and outputs for each step in a process and generating tables where the environmental data are presented to estimate the carbon footprint. They consider that by understanding the carbon emissions on a business process level, it is possible to create opportunities in both an organisational and process level to make improvements in the organisation that would have a direct impact on the environment.

To improve their environmental sustainability, many companies choose to implement certification systems. Cassells et al (2012) mention that process management has proved to have significant effects on the implementation of ISO14000. Poksinska et al (2003) mention that some organisations opt to implement ISO14000, which provides the guidelines for developing an environmental management system. They consider that the implementation of this certification requires management commitment and structure, which can be provided by the integration of ISO9000. This second certification is characterised by a process orientation even when it does not always involve the implementation of process management. Furthermore, Cosimato and Troisi (2015) consider that some greening initiatives can positively affect an organisation's competitiveness when using ISO9001.

Yakob et al (2018) mention that the implementation of environmental management systems can represent different degrees of investment, depending on the company. However, they mention that the investment is usually high, which is the reason why many companies decide to invest in environmentally friendly practices instead of a certified environmental management system. These authors also mention that "globalization has encouraged the emergence of customers who are environmentally conscious and supportive of sustainable green practices". However, they clarify 
that these green practices, such as the adoption of green technology, require the use of improved processes in the companies.

Goyal et al (2018) identified a group of environmental sustainability enablers for supply chains. Among them are:

1. Self-imposed environmental policy: there should be systems in place for the measuring, monitoring and control of practices related to environmental sustainability.

2. Top management commitment: management should be engaged in and committed to the company's environmental development.

3. Reduction of usage of natural resources: this can be done through optimization of resources, more efficient processes and improved product design, among others.

4. Green training/awareness: this enabler involves educating all employees about environmental sustainability.

5. Organizational culture: a common vision should be shared by all the employees to strive towards improved environmental sustainability.

6. Focus on R\&D: there should be a focus on research and development to create environmentally friendly processes and results.

As mentioned in the first section of this paper, the interest of this study is in the potential of process management to enhance environmental sustainability specifically in the freight transport sector. A previous study (Navarro, 2019) evidenced limited availability of literature in this specific business sector with respect to process management and environmental sustainability. However, in logistics, including the transport sector, process management has also been studied and has been found to be able to provide a systemic view and a way to measure sustainable development, including environmental sustainability (Garvare and Isaksson, 2001; Isaksson and Garvare, 2003). Sustainable development is considered to be the path towards achieving sustainability. Näslund (2002) is another researcher that has studied process management in logistics. He mentions that process orientation is a way for logistics to achieve both efficiency and effectiveness in its operations.

\section{Lean and environmental sustainability}

As mentioned before, lean has been applied in many contexts to eliminate waste in all its forms. This section presents the findings from the literature review on how lean has been implemented to achieve environmental sustainability.

Hajmohammad et al (2013) mention that the efforts from lean to reduce waste at an operational level may result in enhancing environmental performance. The authors developed a model in which they suggest that supply management and lean activities might encourage environmental actions and lead to a better environmental performance. Garza-Reyes et al (2016) also mention a combination; they discuss lean and green (referring to efforts for decreasing the environmental impact) and state that the match might seem natural, due to the advocacy to eliminating waste. They mention that lean can increase the competitiveness of organisations and therefore it is considered one of the most dominant managerial paradigms. They state that by combining lean with the environmental thinking it may be possible to develop solutions that allow organisations, specifically within the logistics and transport sector, to achieve environmental sustainability. Similarly, Hartini and Ciptomulyono (2015) consider value stream mapping as a useful tool for identifying environmental impacts.

Carvalho et al (2011) mention that leanness maximizes profit by cost reduction but that there is a need to address environmental practices to ensure sustainable management systems. The authors mention that, in supply chains, lean can result in lower emissions due to reduced inventories but the need for constant replenishment usually increases the emissions. Therefore, in some cases there would be a need to compromise certain factors and not apply the ideal lean configuration to decrease the environmental impact of lean. Similarly, some researchers consider Just in time, which is one of the methods used in lean (Liker and Meier, 2006) to have a negative impact on the 
environment. Ugarte et al (2016), for example, consider that the just in time inventory management presupposes an increase in shipping frequency, which in turn generates higher greenhouse gas emissions and consequently increases the negative impact on the environment. Contrary to this, Green et al (2019) consider that just in time is "directly and positively associated with green supply chain management practices". Additionally, they mention that just in time, total quality management and green supply chain practices can, combined, provide a better environmental performance than when implemented individually.

Fahimnia et al (2015) mention that another aspect that comes from lean is the size of warehouses and transport vehicles. They tested three different scenarios in which they varied the degree to which lean was applied. They found that the case in which a strict lean scenario had been used, the environmental sustainability was the worst compared to less lean situations. They conclude that, even when lean might generate environmental benefits through waste and time reduction, it can also compromise the environmental sustainability if implemented too strictly.

Likewise, Sawhney et al (2007) considered that a lean implementation requires an adaptation to reduce its impact on the environment. They developed the methodology Environmentally Lean (En-Lean), where they refer to four phases that enable the relationships between environmental concerns and lean principles. In this methodology, they studied the environmental impact of each lean principle implemented in a specific organization and determined the effect it had on the environment: negative, positive, neither negative nor positive or no impact at all. To make use of their methodology, they included several environmental performance measurements and lean principles. The authors concluded that the methodology worked as an eye opener for the organisations involved. Just like Sawhney et al (2007), other researchers have focus on the relationship of lean and environmental sustainability in a manufacturing context and developed models to enable this relationship (e.g. Pampanelli et al, 2013; Chiarini, 2014; Bergmiller et al, 2009).

Rothenberg et al (2001) argue that lean practices alone are not able to target all the existing environmental issues. Gibbons et al (2012) consider that a combination of certain methodologies and lean might be a better approach. They developed a value improvement model for repetitive processes. In this model, they combine lean, Six Sigma and systems thinking. They build the model on the conceptual frameworks and strategies of lean and Six Sigma with the purpose of using a system aiming to support business change and thereby generate sustainable competitive advantage, including environmental sustainability.

Garza-Reyes (2015) agrees with the previous authors and states that using lean alone might have certain limitations in achieving environmental sustainability but argues that those limitations can be overcome by the integration of other methodologies, such as Six Sigma.

Among the interests of this study is examining lean and environmental sustainability, focused on the freight transports context. Marcilio et al (2018) developed a survey from which they concluded that there is a possibility to work on the relationship between the organisations and the customers since they found that customers are sometimes willing to pay more for more environmentally sustainable solutions. They see the potential of environmental sustainability to have value for the customer and therefore using a lean thinking could be beneficial. Nonetheless, the authors clarify that there is a possibility for the relationship between lean and green to be conflicting. This conflict relates to the balance between lean solutions that target financial and operational resources and the environmental impact they represent. They also state that different logistics environments might have different results.

Garza-Reyes et al (2017) used value stream mapping, one of the tools within lean, applied to transports, the Transportation Value Stream Map. In this tool, they identified the value adding and non-value adding activities for the transports, classifying the transit and non-transit activities. Later, the authors calculated the Transportation Overall Vehicle Effectiveness, from which they were able to identify wastes. However, in their study they do not evaluate the results according to environmental sustainability. Similarly, Villarreal et al (2017) developed a study using a classification of seven Transportation Extended Wastes and Transportation Value Stream Mapping. These seven 
types of waste (Sternberg et al, 2012) are an adaptation of the different types of waste within the lean philosophy adapted to road transportation. In this study, sustainability was not a part of it.

Garza-Reyes et al (2016) propose the use of Sustainable Transportation Value Stream Map, a variant to the transportation value stream mapping. In this new tool, both operational and environmental wastes are identified and eliminated leaving only activities and elements that have value for the customer. In this way they were able to decrease the environmental impact in a single case.

\section{Analysis}

In this section, the analysis of the findings from the literature review is presented.

\section{Process management and environmental sustainability}

In process management, there was found to be a need to adapt the tools in the methodology. The tools should be adapted to target not only economic and operational efficiency but also environmental sustainability aspects (Houy et al, 2010; Optiz et al, 2014). This will provide a more holistic approach to the current global needs that organisations face. The use of process management might enable the measurement of environmental impact for the entire organisation by measuring the different steps in the processes (Ghose et al 2009; Houy et al, 2010). Most of the research found that involved the measurement of environmental impact in processes involved carbon footprint $\left(\mathrm{CO}_{2}\right)$. In the research, models for measuring the environmental effect from activities (Houy et al, 2010) and input and output of processes (Recker, 2010) can be mentioned.

On a more managerial level, certain companies seem to opt for certification systems such as ISO 14000. Researchers found that the use of a process perspective, usually by the means of ISO 9001 can support the implementation and increase the environmental sustainability (Poksinska, 2003; Casells et al 2012; Cosimato and Troisi, 2015). ISO9001 provides a process orientation to the company and the combination of the two certification systems seems to provide better results for environmental sustainability. It could be speculated that if an organisation were to venture on a process management implementation, which is completely process oriented, the support for ISO14000 could be even stronger and might even facilitate the achievement of environmental sustainability. However, it should be also considered that the implementation of environmental management systems, such as ISO 14000, requires a considerable investment. High investments for certificate management systems might not be a priority for SMEs in the freight transport sector. More specifically, the investment of these kinds of companies might be prioritised to favour the value of the investments instead of the impact on the environmental aspects related to the company. Nonetheless, the use of processes which are structured and clear might facilitate the development of environmental practices (Yakob et al, 2018).

Additionally, among the enablers identified by Goyal et al (2018), there are several aspects linked to, and that can be facilitated by, the use of process management. Some of these aspects are top management commitment, the involvement of everyone, process improvement, monitoring and control. There could be a potential, as mentioned by other researchers (i.e. Poksinska, 2003; Ghose et al, 2009; Houy et al, 2010; Casells et al, 2012) for process management to facilitate these aspects for environmental sustainability.

Some of the identified challenges for implementing process management to achieve environmental sustainability include the focus of the methodology in targeting operational and economic benefits which needs to evolve to include environmental aspects too (Houy et al, 2010). Another of the challenges found is the current lack of experience in this subject. Since this is a novel area, there is still a need for further research and empirical studies that could guide the utilisation of this tool for achieving environmental sustainability.

Maletič et al (2014; 2015) suggested that process management not only supports environmental sustainability from an 'as is' organisation point of view but even facilities the finding of new opportunities by supporting innovation for environmental sustainability. This argument supports 
the consideration that process management might enable environmentally sustainable development from an operative and a strategic level.

When referring specifically to the use of process management to achieve environmental sustainability in the freight transport sector, the findings were limited. However, when looking at the logistics context, several researchers were found who consider that process management provides a systemic view and an approach for measuring performance, including environmental sustainability (Garvare and Isaksson, 2001; Isaksson and Garvare, 2003; Näslund, 2002). This systemic view and the measuring of the different activities in the process could provide a way to increase efficiency and effectiveness, not only in operational and economic aspects but even in environmental ones when environmental parameters, goals and practices are included in the equation.

Referring to the purpose of this paper, process management could have the potential to enhance environmental sustainability by providing companies with the structure needed to manage, prioritise and measure environmental practices. This methodology has been used at a strategic level and has the potential to provide strategic ways for companies interested in achieving environmental sustainability. However, there is a need for more research, at both theoretical and empirical levels.

\section{Lean and environmental sustainability}

The findings related to lean and environmental sustainability evidence that the research of the effects of lean on environmental sustainability is more extensive than that of process management. Several researchers see a potential for lean to support environmental sustainability. Some of them consider the objective of lean, eliminating waste, to be a good predisposition for enhancing environmental performance (Hajmohammad et al, 2013; Carvalho et al, 2011; Sawhney et al, 2007). Among the benefits of using lean was the fact that by eliminating the types of waste described by Liker and Meier (2006), the environmental impact could be reduced, for example, by including a reduction in material waste and inventories. However, some of the tools and principles of lean can be considered to act against environmental sustainability. For example, the use of just in time, which, as argued by many authors, represents in most cases an increase in the number of transports, which in turn increases the organisations' negative emissions. Therefore, many researchers agree in stating that lean cannot be applied strictly or alone if the intention to decrease the environmental impact is present (Rothenberg et al, 2001; Gibbons et al, 2012; Garza-Reyes, 2015). Some of the combinations mentioned by the authors that could increase the potential of lean to enhance environmental sustainability are Six Sigma and green management. In some cases, it might be that the reduction in wastes from an operational and economic perspective, compared to the increase of negative impact from other solutions, might tip the scale towards a worse environmental impact. Moreover, based on the results of the literature review, it is imperative for lean not only to adapt and pursue economic benefits but also to contemplate the environmental issues when being implemented.

The use of lean, specifically the use of just in time, is argued to be beneficial for enhancing the environmental performance (Green et al, 2019). However, due to the nature of the road freight transport companies and the already existing problem of the increase in transports, the use of this tool could affect these companies and represent additional management challenges.

With a focus on the freight transport sector, there seems to be a potential to involve the customers. As mentioned by Marcilio et al (2018), some customers might be interested in choosing more environmentally sustainable solutions, even when the costs are higher. This suggests that environmental sustainability might signify value for customers. Lean is about eliminating wastes and doing activities that represent a value for the customer. Therefore, the application of lean would help increase value for customers in terms of environmental sustainability.

Among the results, some lean tools have been identified as ways to generate operational improvements; for example, the use of transportation value stream mapping and the classification of wastes into transport extended wastes. However, the results involving environmental 
sustainability are limited and evidence the need for more research in this area. The results and their publication dates also suggest the novelty of the research area and a possible trend for upcoming research in this area.

Referring to the purpose of this paper, lean could have potential to enhance environmental sustainability due to companies' predisposition to identify and eliminate waste. There also seems to be a trend in which the research in this area is increasing. The efforts that have been made to use lean as a means for achieving environmental sustainability are at an operational level. However, there is a need for more research, at both the theoretical and the empirical level. In the freight transport sector, the literature for this research area was found to be limited, which evidences the need for future research.

\section{Conclusions}

In response to RQ1, process management has been used to provide the structure for measuring the environmental impact of certain companies. Moreover, ISO 14000, an environmental management system, has been supported by a process view. However, literature is limited on the ways process management has been used for the freight transports sector.

In answering RQ2, the literature shows that some Lean tools from lean, such as value stream mapping, have been useful for identifying wastes from an environmental perspective. Similar approaches were identified to be used in the freight transport sector. Literature evidence that the extent of the use of lean is broader than that of process management for achieving the purpose of having less environmental impact.

As a conclusion for RQ3 and RQ4, both QM concepts, process management and lean, may have the potential to support the enhancement of environmental sustainability. Nonetheless, a distinction must be done in that the approach for targeting environmental sustainability with lean has a higher potential at the operative level while process management has a higher potential at the strategic level. However, it is imperative to mention that these two research questions require additional support from empirical research in order to answer them more adequately.

Moreover, process management and lean require adaptations in order to be useful for helping in the greening of the freight transport sector. There is a need for them to evolve from economic and resources effective approaches to approaches with a broader way of thinking, including environmental sustainability as an objective. The freight transport sector could gain benefits from the use of both QM concepts. However, while research has been done to target transports with the use of lean for enhancing environmental sustainability, process management has not been researched in depth. Indeed, this leaves a gap which can be explored and hopefully filled. This business sector faces tough challenges and difficult goals on environmental impact. Furthermore, new techniques are constantly introduced to this business sector and logistics in general. Some of these techniques are upgraded vehicles with lower negative environmental emissions, new management approaches with a stronger coordination between the stakeholders and new infrastructure on the roads and systems provided by governments. Certainly, these new challenges for the business sector might find benefits in targeting environmental sustainability from a strategic level. Process management could support this work by providing the means for dealing with and fulfilling the new demands and possibilities embedded in the strive towards environmental sustainability.

The propositions presented in this study are limited by the need to test them in practice. Therefore, empirical research is suggested as a next step to investigate the effects of using process management and lean manufacturing to enhance environmental sustainability, specifically for organisations of the road freight transport sector. Nonetheless, this study contributes to identifying and filling the gap presented in this paper. Furthermore, it might constitute a basis for future research in the possibilities for QM to enhance environmental sustainability by mapping and identifying the state of art of the subject in question.

\section{References}


Antony, J., Krishan, N., Cullen, D. and Kumar, M. (2012). "Lean Six Sigma for higher education institutions (HEIs): Challenges, barriers, success factors, tools/techniques”. International Journal of Productivity and Performance Management. 61(8), pp. 940-948.

Aronsson, H. and Brodin, M. H. (2006) "The environmental impact of changing logistics structures", The International Journal of Logistics Management, 17(3), pp. 394 - 415.

Balzarova, M.A., Bamber, C.J., McCambridge, S. and Sharp, J.M. (2004) "Key success factors in implementation of process-based management: A UK housing association experience", Business Process management Journal, 10(4), 387-399.

Bednár, R., Vidová, H. and Beluský, M. (2012). "Lean principles application in business logistics". METAL 2012 - Conference Proceedings, 21st International Conference on Metallurgy and Materials 2012, Pages 1762-1768.

Bergman, B. and Klefsjö, B. (2010) Quality from Customer Needs to Customer Satisfaction. Studentlitteratur. Lund, Sweden.

Bergmiller, G.G. Mccright, P.R. and Florida, S. (2009) "Lean Manufacturers' Transcendence to Green Manufacturing," Industrial Engineering Research Conference, pp.1144-1148.

Brundtland, G. H. (1987) Our Common Future: Report of the World Commission on Environment and Development, Medicine, Conflict and Survival.

Carvalho, H., Duarte, S., and Machado, V.C. (2011) "Lean, agile, resilient and green: divergencies and synergies". International Journal of Lean Six Sigma. 2(2), pp.151-179.

Cassells, S., Lewis, K. V, Findlater, A. and Cassells, S. (2012) “An exploration of ISO 14001 uptake by New Zealand firms", International Journal of Law and Management, 54(5), pp.345-363.

Chiarini, A. (2014) "Sustainable manufacturing-greening processes using specific Lean Production tools: an empirical observation from European motorcycle component manufacturers," Journal for CLeaner Production. 85, pp. 226-233.

Cosimato, S. and Troisi, O. (2015) "Green supply chain management", Journal of Manufacturing Technology Management, 27(2), pp. 256-276.

Cronemyr, P. (2007) Six Sigma Management Action research with some contributions to theories and methods. Division of Quality Sciences. Chalmers University of Technology. Gothenburg, Sweden.

Cronemyr, P. and Danielsson, M. (2013), Process management 1-2-3 - maturity model and diagnostics tool, Total Quality Management \& Business Excellence, 24:7-8, pp.933-944.

Davenport, T.H. (1993). Process Innovation: Reengineering Work Through Information Technology. Harvard Business Press.

De Souza, L.B. (2009). "Trends and approaches in Lean healthcare". Leadership in Health Services. 22(2), pp. 121-139.

Evangelista, P., Huge-Brodin, M., Isaksson, K. and Sweeney, E. (2013) "Purchasing Green Transport and Logistics Services: Implications from the Environmental Sustainability Attitude of 3PLs", in Information Resources Management Association (ed.), Sustainable practices: concepts, methodologies, tools, and applications. 1, IGI Global, pp. 86-102.

Fahimnia, B., Sarkis, J. and Eshragh, A. (2015). "A tradeoff model for green supply chain planning: A Leanness-versus-greenness analysis". Omega. 54, pp.173-190

Garvare, R. and Isaksson, R. (2001) "Sustainable development: extending the scope of business", Measuring Business Excellence, 5(3), pp. 11-15.

Garvare, R. \& Johansson, P. (2010) Management for sustainability - A stakeholder theory. Total Quality Management and Business Excellence, 21(7), pp. 737-744.

Garza-Reyes, J.A. (2015), "Green Lean and the need for Six Sigma”, International Journal of Lean Six Sigma, 6(3), pp. 226-248.

Garza-Reyes, J.A., Villarreal, B., Kumar, V. and Molina Ruiz, P. (2016). "Lean and green in the transport and logistics sector - a case study of simultaneous deployment", Production Planning \& Control. 27(15), pp.1221-1232. 
Garza-Reyes, J.A., Beltran Forero, J.S., Kumar, V., Villarreal, B., Cedillo-Campos, M.G. and RochaLona, L. (2017). "Improving Road Transport Operations using Lean Thinking". Procedia Manufacturing. 11, pp.1900-1907.

Ghobakhloo, M., Hong, T.S (2014). "IT investments and business performance improvement: The mediating role of Lean manufacturing implementation". International Journal of Production Research. 52(18). pp. 5367-5384.

Ghose, A., Hoesch-Klohe, K., Hinsche, L. and Le, L. (2009) "Green business process management: a research agenda. Australaisian Journal of Information Systems, Vol.16, No.2, pp. 103117.Giroux, H. (2006), 'It Was Such a Handy Term': Management Fashions and Pragmatic Ambiguity, Journal of Management Studies 43(6), pp. 1227-1260.

Gibbons, P.M, Kennedy, C., Burgess, S. and Godfrey, P. (2012) "The development of a value improvement model for repetitive processes (VIM): Combining Lean, Six Sigma and systems thinking". International Journal of Lean Six Sigma. 3(4), pp.315-338

Goyal, S.; Routroy, S. and Shah, H. (2018) "Measuring the environmental sustainability of supply chain for Indian steel industry A graph theoretic approach". Business Process Management Journal 24(2), pp. 517-536.

Green, K.W.; Inman, R.A.; Sower, V.E. and Zelbst, P.J. (2019) "Impact of JIT, TQM and green supply chain practices on environmental sustainability". Journal of Manufacturing Technology Management. 30(1), pp. 26-47.

Hajmohammad, S., Vachon, S. Klassen, R.D. and Gavronski, I. (2013) "Lean management and supply management: their role in green practices and performance," Journal for CLeaner Production. 39, pp. 312-320.

Hammer M. and Champy, J. (1993) Reengineering the corporation. Harper Business.

Harrington, H.J. (1991) Business Process Improvement. USA: McGraw-Hill Education

Hartini, S. and Ciptomulyono, U. (2015). "The relationship between Lean and sustainable manufacturing on performance: literature review". Procedia Manufacturing. 4, pp.38-45.

Houy, C., Reiter, M., Fettke, P., Loos, P., (2010) Towards Green BPM - Sustainability and Resource Efficiency through Business Process management in: zur Muehlen, M., Su, J. (eds.) Business Process management Workshops, BPM 2010 International Workshops and Education Track Hoboken, NJ, USA, September 2010, Revised Selected Papers, Springer, Heidelberg, Germany, 511-520.

Isaksson, K. (2012) Logistics Service Providers going green- insights from the Swedish market. Linköping University.

Isaksson, R. and Garvare, R. (2003) "Measuring sustainable development using process models", Managerial Auditing Journal, 18(8), pp649-646.

Kuei, C.-H. \& H. Lu, M. (2013) Integrating quality management principles into sustainability management. Total Quality Management and Business Excellence, 24(1), pp. 62-78.

Liker, J.K. and Meier, D. (2006). The Toyota way fieldbook - A practical guide for implementing Toyota's 4Ps. McGraw-Hill

Maletič, M.; Maletič, D.; Dahlgaard, J. J. and Dahlgaard-Park, S.M. (2014). "Sustainability exploration and sustainability exploitation: from a literature review towards a conceptual framework". Journal of CLeaner Production. 79, pp. 182-194.

Maletič, M.; Maletič, D.; Dahlgaard, J. J.; Dahlgaard-Park, S.M. and Gomišcek, B. (2014). "Do corporate sustainability practices enhance organizational economic performance?". International Journal of Quality and Service Sciences. 7(2/3), pp. 184-200.

Márquez-Ramos, L. (2015) "The relationship between trade and sustainable transport: A quantitative assessment with indicators of the importance of environmental performance and agglomeration externalities”, Ecological Indicators. Elsevier Ltd, 52 (March 2014), pp. 170183. 
Marcilio, G.P., Rangel, J.J.D.A., Souza, C.L.M.D., Shimoda, E., Silva, F.F.D., Peixoto, T.A. (2018). "Analysis of greenhouse gas emissions in the road freight transportation using simulation". Journal for CLeaner Production. 170, pp.298-309.

Martinsen, U. and Huge-Brodin, M. (2014) "Environmental practices as offerings and requirements on the logistics market", Logistics Research, 7(1).

Navarro, P. (2019). Exploring process management as a means for greening road freight transport. Department of Management and Engineering. Linköping University. Linköping, Sweden

Näslund, D. (2002). "Logistics for Managing and Improving Processes". Supply Chain Forum: An International Journal. 3(2), pp.48-57.

Opitz, N., Krüp, H. and Kolbe, L.M. (2014). "Green Business Process management - A Definition and Research Framework". 47th Hawaii International Conference on System Science.

Paim, R., Caulliraux, H.M., Cardoso, R. (2008). "Process management tasks: a conceptual and practical view", Business Process management Journal, 14(5), 694-723.

Palmberg, K. (2009) "Exploring process management: are there any widespread models and definitions?", The TQM Journal, (21), 2, 203-216.

Palmberg, K. (2010) Experiences of implementing process management: a multiple-case study. Business Process Management Journal, 16(1), pp. 93-113.

Pampanelli, A.B., Found, P. and Bernardes, A.M. (2013) "A Lean \& Green Model for a production cell," Journal for CLeaner Production. 85, pp. 19-30.

Poksinska, B. (2010) "When does ISO 9000 lead to improvements?", International Journal of Productivity and Quality Management, (5), 2, 124-136.

Poksinska, B., Dahlgaard, J. J. and Eklund, J. a. E. (2003) "Implementing ISO 14000 in Sweden: motives, benefits and comparisons with ISO 9000", International Journal of Quality \& Reliability Management, Vol. 20, No. 5, pp. 585-606.

Prajogo, D., Oke, A. and Olhages, J. (2016). "Supply chain processes: Linking supply logistics integration, supply performance, Lean processes and competitive performance". International Journal of Operations and Production Management. 36(2), pp. 220-238.

Psomas, E.L., Fotopoulos, C.V. and Kafetzopoulos, D.P. (2011). "Core process management practices, quality tools and quality improvement in ISO 9001 certified manufacturing companies", Business Process management Journal, 17 (3), 437-460.

Recker, J., Rosemann, M. and Gohar, E.R. (2010) Towards Green BPM - Sustainability and Resource Efficiency through Business Process management in: zur Muehlen, M., Su, J. (eds.) Business Process management Workshops, BPM 2010 International Workshops and Education Track Hoboken, NJ, USA, September 2010, Revised Selected Papers, Springer, Heidelberg, Germany, 511-520.

Rothenberg, S., Pil, K.F. and Maxwell, J. (2001). "Lean, green, and the quest for superior environmental performance*". Production and Operations Management. 10(3).

Sawhney, R., Teparakul, P. Bagchi, A. and Li, X. (2007) "En-Lean: a framework to align Lean and green manufacturing in the metal cutting supply chain," International Journal Enterprise Network Management. 1(3), p. 238-260.

Shewhart, W. A. (1931) Economic control of quality and manufactured product. Van Nostrand, New York.

Shewhart, W. A. (1939) Statistical method from the viewpoint of quality control. Graduate School of the Department of Agriculture, Washington D. C.

Smith, K. H. (2012) Reviews: From Systematic to Narrative LHL Guides at UAB Lister Hill Library of the Health Sciences. Available at: http://libguides.lhl.uab.edu/sysrev (Accessed: 20 December 2016).

Snyder, H. (2019) Literature review as a research methodology: An overview and guidelines. Journal of Business Research, 104, pp. 333-339. 
Sternberg, H., Stefansson, G., Westernberg, Boije af Gennäs, R., Allenström, E. and Linger Nauska, M. (2012) "Applying a Lean approach to identify waste in motor carrier operations". International Journal of Productivity and Performance Management. 62(1), pp.47-65.

Sörqvist, L. (2013) Lean - Processutveckling med focus på kundvärde och effektiva flöden (In Swedish, English translation: Lean - Process improvement with focus on customer value and flow efficiency). Studentlitteratur. Lund, Sweden

Ugarte, G.M, Golden, J.S and Dooley, K.J (2016). "Lean versus green: The impact of Lean logistics on greenhouse gas emissions in consumer goods supply chains". Journal of Purchasing and Supply Management. 22(2), pp. 98-109.

Villarreal, B., Garza-Reyes, J.A., Kumar, V. and Lim, M.K. (2017) "Improving road transport operations through Lean thinking: a case study" International Journal of Logistics Research and Applications. 20(2), pp.163-180.

Womack, J.P. and Jones, D. (2003) Lean Thinking. $2^{\text {nd }}$ Ed., Free Press. New York, USA.

Womack, J.P., Jones, D. T. and Roos, D. (1990) The machine that changed the world. Harper Perennial. New York, USA.

Yakob, P.; Wong, L.S. and Khor, S.C. (2018) "An empirical investigation of green initiatives and environmental sustainability for manufacturing SMEs". Journal of Manufacturing Technology Management. 30(1), pp. 2-25. 